\title{
Quantitative trait loci for Aluminum resistance in wheat cultivar Chinese Spring
}

\author{
Hong-Xiang $\mathrm{Ma}^{1,3}$, Gui-Hua Bai ${ }^{2,4}$ \& Wei-Zhong $\mathrm{Lu}^{3}$ \\ ${ }^{1}$ Department of Agronomy, Kansas State University, Manhattan, KS 66506, USA. ${ }^{2}$ USDA-ARS, Plant \\ Science and Entomology Research Unit, 4008 Throckmorton Hall, Manhattan, KS 66506, USA. ${ }^{3}$ Jiangsu \\ Academy of Agricultural Sciences, 210014, Nanjing, China. ${ }^{4}$ Corresponding author*
}

Received 7 September 2005. Accepted in revised form 9 January 2006

Key words: Aluminum resistance, ditelosomic lines, QTL mapping, Triticum aestivum

\begin{abstract}
Aluminum (Al) toxicity is one of the major constrains for wheat production in many wheat growing areas worldwide. Further understanding of inheritance of Al resistance may facilitate improvement of Al resistance of wheat cultivars (Triticum aestivum L.). A set of ditelosomic lines derived from the moderately Alresistant wheat cultivar Chinese Spring was assessed for Al resistance. The root growth of ditelosomic lines DT5AL, DT7AL, DT2DS and DT4DS was significantly lower than that of euploid Chinese Spring under Al stress, suggesting that Al-resistance genes might exist on the missing chromosome arms of 5AS, 7AS, 2DL and 4DL of Chinese Spring. A population of recombinant inbred lines (RILs) from the cross Annong $8455 \times$ Chinese Spring-Sumai 37 A substitution line was used to determine the effects of these chromosome arms on Al resistance. A genetic linkage map consisting of 381 amplified fragment length polymorphism (AFLP) markers and 168 simple sequence repeat (SSR) markers was constructed to determine the genetic effect of the quantitative trait loci (QTLs) for Al resistance in Chinese Spring. Three QTLs, Qalt.pser-4D, Qalt.pser-5A and Qalt.pser-2D, were identified that enhanced root growth under Al stress, suggesting that inheritance of Al resistance in Chinese Spring is polygenic. The QTL with the largest effect was flanked by the markers of $X c f d 23$ and $X w m c 331$ on chromosome 4DL and most probably is multi-allelic to the major QTL identified in Atlas 66. Two additional QTLs, Qalt.pser-5A and Qalt.pser-2D on chromosome 5AS and 2DL, respectively, were also detected with marginal significance in the population. Some SSR markers identified in this study would be useful for marker-assisted pyramiding of different QTLs for Al resistance in wheat cultivars.
\end{abstract}

Abbreviations: AFLP - amplified fragment length polymorphism; Al - Aluminum; DT - ditelosomic line; QTL - quantitative trait locus; RILs - recombinant inbred lines; SSR - simple sequence repeat

\section{Introduction}

Aluminum (Al) toxicity is one of the major constrains for crop production in acid soils where low $\mathrm{pH}$ facilitates the release of $\mathrm{Al}^{3+}$ into the soil solution. This trivalent cation is toxic to the

\footnotetext{
*FAX No: + 1-785-532-6167.

E-mail: gbai@ksu.edu
}

plant root system by limiting root growth and development (Kochian, 1995). Al toxicity is the primary limitation on crop production for $37.9 \%$ of farmland in Southeast Asia, 30.9\% of Latin America, and approximately $20 \%$ in East Asia, Sub Saharan Africa, and North America (Wood et al., 2000). High sensitivity of wheat to Al stress directly threatens food security in many areas where food security is most tenuous. 
Furthermore, in developed countries such as the United States, extensive farming practices such as the extensive use of ammonia fertilizers and continuous removing cations from soils through harvesting grain crops are causing further acidification of agricultural soils, creating new acid soils from previously neutral ones (Jackson and Reisenauer, 1984).

There is a wide range of genetic variation in Al resistance, both within and across plant species (Delhaize and Ryan, 1995; Ryan et al., 1995; Taylor, 1988). The genetic analysis of Al resistance has been an active area of research for several decades. The genetic architecture of $\mathrm{Al}$ resistance in wheat (Triticum aestivum L.) is still equivocal, being proposed to be monogenic in some studies but polygenic in the others. Evaluation of $\mathrm{Al}$ resistance in populations from the crosses between cultivars contrasting in Al resistance suggested that $\mathrm{Al}$ resistance was attributed to the action of a single dominant gene (Delhaize et al., 1993; Riede and Anderson, 1996) that was located on chromosome 4DL (Riede and Anderson, 1996; Rodriguez-Milla and Gustafson, 2001). Studies on ditelosomic lines of the moderately Al-resistant wheat cultivar Chinese Spring indicated a polygenic control of $\mathrm{Al}$ resistance in wheat. When $\mathrm{Al}$ resistance was assayed by root re-growth after Al stress, Chinese Spring lacking of chromosome arms 5AS, 6AL, 7AS, 2DL, 3DL, or 4DL showed reduced $\mathrm{Al}$ resistance relative to the euploid Chinese Spring, suggesting that each of these missing chromosome arms might be involved in Al resistance (Aniol, 1990; Aniol and Gustafson, 1984; Papernik et al., 2001; Takagi et al., 1983).

Molecular marker and genome mapping allow one to identify individual chromosomal region containing genetic factors that contribute to variation in a complex trait. They have been extensively used to dissect complex traits such as Al resistance in wheat and other cereal crops (Luo and Dvorak, 1996; Magalhaes et al., 2004; Miftahudin et al., 2004; Nguyen et al., 2001, 2003; Riede and Anderson, 1996; Sibov et al., 1999; Wu et al., 2000). In wheat, Riede and Anderson (1996) identified a single gene $\left(A l t_{B H}\right)$ for Al resistance on 4DL of $\mathrm{BH} 1146$ by using an RFLP marker. Further study of the same population demonstrated that Alt $_{B H}$ was located to a $5.9-\mathrm{cM}$ interval between markers $\mathrm{Xgdm} 125$ and Xpsr914 on 4DL (Rodriguez-Milla and Gustafson, 2001). In Chinese Spring, another gene for Al resistance, Alt2, was reported from the same chromosome arm by using disomic substitution lines (Luo and Dvorak, 1996).

Our objectives in this study were to evaluate the responses of ditelosomic lines of Chinese Spring to Al stress and to identify genetic loci for Al resistance in Chinese Spring by QTL mapping.

\section{Materials and methods}

\section{Plant materials}

Seeds of wheat cultivar Chinese Spring (Triticum aestivum L.) and its ditelosomic lines were provided by Wheat Genetics Resource Center, Kansas State University, Manhattan, KS, USA. Because loss of a chromosome arm caused sterility in some ditelosomic lines, only 31 ditelosomic lines were used for evaluation of $\mathrm{Al}$ resistance.

The mapping population consisted of $90 \mathrm{~F}_{6}$ RILs derived by single-seed descent from the cross of Annong 8455/CS-SM3DS7A. CS-SM3DS7A has all chromosomes of Chinese Spring except for chromosome 7A substituted by the same chromosome of cultivar Sumai 3 (Zhou et al., 2002). Chinese Spring is a landrace from China with moderate $\mathrm{Al}$ resistance, whereas Annong 8455 is an Al-sensitive cultivar released from Anhui Agricultural University in China.

\section{Al resistance of Chinese Spring and its derivatives}

Ditelosomic lines and euploid of Chinese Spring, the mapping population of RILs and their parents were evaluated for Al resistance by measuring root growth of each line after Al stress. Wheat seeds were placed on moist paper in a petri dish. The seeds were incubated at $4{ }^{\circ} \mathrm{C}$ for $24 \mathrm{~h}$ and then moved to room temperature (22$25^{\circ} \mathrm{C}$ ) for another $24 \mathrm{~h}$. Three germinated seeds with similar root lengths were selected and transferred onto a nylon-net at the bottom of a plastic cup with the bottom removed. Cups with germinated seeds were placed in a 30 -well plastic cup holder. The cup holder floated on 7-L of deionized water in a $27-\mathrm{L}$ plastic tray. Two bubble 
rods in the bottom of each tray were connected to an air pump for aeration during hydroponics culture. After $48 \mathrm{~h}$, the deionized water was replaced with a nutrient solution consisting of $4 \mathrm{mM} \quad \mathrm{CaCl}_{2}, \quad 6.5 \mathrm{mM} \quad \mathrm{KNO}_{3}, \quad 2.5 \mathrm{mM}$ $\mathrm{MgCl}_{2} \cdot 6 \mathrm{H}_{2} \mathrm{O}, 0.1 \mathrm{~m} M(\mathrm{NH} 4)_{2} \mathrm{SO}_{4}$, and $0.4 \mathrm{mM}$ $\mathrm{NH}_{4} \mathrm{NO}_{3}$ (Polle et al., 1978). The $\mathrm{pH}$ of the nutrient solution was set at 4.0, and monitored and adjusted daily.

After incubated in the nutrient solution for $24 \mathrm{~h}$ at $22{ }^{\circ} \mathrm{C}$ with $16 \mathrm{~h}$ of fluorescent light, the longest root of each seedling was measured to the nearest millimeter from the bottom of the plastic cup to the tip of the root. The seedlings were then transferred to a fresh nutrition solution, with addition of $0.36 \mathrm{~m} M \mathrm{AlK}\left(\mathrm{SO}_{4}\right) \cdot 2 \mathrm{H}_{2} \mathrm{O}$ at $\mathrm{pH}$ 4.0. After $48 \mathrm{~h}$ of $\mathrm{Al}$ stress, the same root in each seedling was measured again. The same procedure was followed for control plants, except without addition of $\mathrm{AlK}\left(\mathrm{SO}_{4}\right) \cdot 2 \mathrm{H}_{2} \mathrm{O}$ in the nutrition solution. The experiment was repeated three times at different dates. Root elongation during $48 \mathrm{~h}$ of $\mathrm{Al}$ stress was referred to as stress root growth (SRG). Root elongation in the control solution $\left(0 \mathrm{mM}\right.$ AlK $\left.\left(\mathrm{SO}_{4}\right) \cdot 2 \mathrm{H}_{2} \mathrm{O}\right)$ during $48 \mathrm{~h}$ was described as control root growth (CRG). The root-resistance index (RRI) (\%) for each line in each replication was calculated as $100 \times$ SRG $/$ CRG.

\section{SSR and AFLP analysis}

A total of 1013 pairs of SSR primers were screened between parents, including 101 GWM primers (Röder et al., 1998), 432 BARC primers (Song et al., 2005), 374 WMC primers (Somers et al., 2004), 8 GDM primers (Pestsova et al., 2000), and 98 CFD or CFA primers (Guyomarc'h et al., 2002; Sourdille et al., 2003). The PCR reactions were performed in a DNA Engine Tetrad ${ }^{\circledR}$ Peltier thermal cycler (MJ Research, Waltham, MA, USA). A $10-\mu \mathrm{L}$ PCR mixture contained $40 \mathrm{ng}$ of template DNA, $0.1 \mu \mathrm{M}$ of each primer, $0.2 \mathrm{mM}$ of each dNTP, $1 \times$ PCR buffer, $2.5 \mathrm{mM} \mathrm{MgCl}$, and 0.6 units of Taq polymerase (Promega, Madison, WI, USA). Forward primer was labeled with IRDye-700 or -800 (Li-Cor, Lincoln, NE, USA). A touch-town program was used for PCR amplification, in which the reaction incubated at $95^{\circ} \mathrm{C}$ for $5 \mathrm{~min}$, then continued for five cycles of $45 \mathrm{~s}$ at $95{ }^{\circ} \mathrm{C}, 5 \mathrm{~min}$ at $68{ }^{\circ} \mathrm{C}$ with a decrease of $2{ }^{\circ} \mathrm{C}$ in subsequent cycles, and $1 \mathrm{~min}$ at $72{ }^{\circ} \mathrm{C}$. For another five cycles, the annealing temperature started at $58^{\circ} \mathrm{C}$ for $2 \mathrm{~min}$ with a decrease of $2{ }^{\circ} \mathrm{C}$ for each subsequent cycle. Then, PCR went through an additional 25 cycles of $45 \mathrm{~s}$ at $94{ }^{\circ} \mathrm{C}, 2 \mathrm{~min}$ at $50{ }^{\circ} \mathrm{C}$, and $1 \mathrm{~min}$ at $72{ }^{\circ} \mathrm{C}$ with a final extension at $72{ }^{\circ} \mathrm{C}$ for $5 \mathrm{~min}$.

For AFLP analysis, $300 \mathrm{ng}$ template DNA was double digested with PstI and MseI restriction enzymes and ligated to corresponding AFLP adaptors before pre-amplification. For pre-amplification, $40 \mu \mathrm{L}$ PCR mixture consisted of $1 \times$ PCR buffer, $2.5 \mathrm{mM}$ of $\mathrm{MgCl}_{2}$, $0.2 \mathrm{~m} M$ of dNTP mix, $75 \mathrm{ng}$ each of unlabeled PstI (5'-GACTGCGTACATGCAG) and $\mathrm{Mse}$ I (5'-GATGAGTCCTGAGTAA) primers, $0.75 \mathrm{u}$ of $\mathrm{Taq}$ polymerase and $10 \mu \mathrm{L}$ of ten-fold diluted DNA. PCR was run for 25 cycles at $94{ }^{\circ} \mathrm{C}$ for $30 \mathrm{~s}$, at $56^{\circ} \mathrm{C}$ for $60 \mathrm{~s}$, and at $72{ }^{\circ} \mathrm{C}$ for $60 \mathrm{~s}$. The pre-amplified PCR product was then used as a template for further selective amplification. A $10 \mu \mathrm{L}$ of selective PCR mixture contained $2 \mu \mathrm{L}$ of ten-fold diluted preamplified DNA, $1 \times$ PCR buffer, $2.5 \mathrm{mM}$ of $\mathrm{MgCl}_{2}, 0.2 \mathrm{mM}$ of dNTP mix, $10 \mathrm{ng}$ of unlabeled MseI primer, 0.35 pmol of IR dye-labeled Pst I primer and $0.2 \mathrm{u}$ of Taq polymerase. The PCR was run at $94{ }^{\circ} \mathrm{C}$ for 2 min followed by 13 cycles of $94{ }^{\circ} \mathrm{C}$ for $30 \mathrm{~s}, 65^{\circ} \mathrm{C}$ for $30 \mathrm{~s}$ with a touchdown temperature of $-0.7^{\circ} \mathrm{C} /$ cycle in each following cycle, and $72{ }^{\circ} \mathrm{C}$ for $60 \mathrm{~s}$ followed by additional 23 cycles of $94^{\circ} \mathrm{C}$ for $30 \mathrm{~s}$, $56{ }^{\circ} \mathrm{C}$ for $30 \mathrm{~s}, 72{ }^{\circ} \mathrm{C}$ for $60 \mathrm{~s}$. To detect AFLP products, PstI primers were labeled with either IRDye-700 or -800 fluorescent dyes compatible with the Li-Cor DNA analyzer (Li-Cor Inc, Lincoln, NE, USA). PCR products were mixed with $5 \mu \mathrm{L}$ of formamide loading dye from Li-Cor (Li-Cor, Lincoln, NE, USA).

The PCR products of simple sequence repeat (SSR) and AFLP were denatured for $5 \mathrm{~min}$ at $94{ }^{\circ} \mathrm{C}$, and then quickly cooled on ice. To $20 \mathrm{~mL}$ of $6.5 \%$ Gel Matrix (Li-Cor, Lincoln, NE, USA), $75 \mu \mathrm{L}$ of $20 \%$ ammonium persulfate and $15 \mu \mathrm{L}$ TEMED were added right before the gel was cast with $25-\mathrm{cm}$ glass plates from Li-Cor ( $\mathrm{Li}-$ Cor, Lincoln, NE, USA). The gel was cast at least $1 \mathrm{~h}$ in advance and was pre-run in $1 \times \mathrm{TBE}$ buffer (50 mM TRIS, $50 \mathrm{mM}$ boric acid, $1 \mathrm{mM}$ 
EDTA) for $10 \mathrm{~min}$ before the samples were loaded. A sample of $0.8 \mu L$ was loaded into each well of the gel. The electrophoresis condition was set at $1500 \mathrm{~V}, 40 \mathrm{~W}$ at $45{ }^{\circ} \mathrm{C}$. The gel image was collected simultaneously as the electrophoresis progressed by a scanner inside the analyzer, and was visualized on a computer screen.

\section{Data analysis}

Standard analysis of variance (ANOVA) was performed to test the significant differences among ditelosomic lines and RILs by using SAS (SAS Institute Inc, Cary, NC. USA). Broadsense heritability $\left(h^{2}\right)$ was computed as $\sigma_{\mathrm{g}}{ }^{2} /$ $\left(\sigma_{\mathrm{g}}{ }^{2}+\sigma_{\mathrm{e}}{ }^{2}\right)$ based on the estimates of genetic and error variances. Linkage map of the SSR and AFLP markers was constructed by using Joinmap ${ }^{\circledR}$ 3.0 (Van Ooijen and Voorrips, 2001). MapQTL® 5 was used for composite interval mapping and estimation of determination coefficients $\left(R^{2}\right)$ (Van Ooijen, 2004). Threshold of the LOD value to declare a significant QTL was determined by running 1000 permutations.

\section{Results}

Al resistance in ditelosomic lines

of Chinese Spring

The ditelosomic lines and euploid of Chinese Spring were evaluated for Al resistance by measuring the root growth of these lines under Al stress in comparison with root growth of nonAl-stressed seedlings of the same lines in three times. Plants were grown hydroponically with a full-strength of nutrient solution containing $0.36 \mathrm{mM} \mathrm{AlK}\left(\mathrm{SO}_{4}\right)_{2}$ at $\mathrm{pH}$ 4.0. CRG, SRG, and RRI were measured for each line after $48 \mathrm{~h}$ of $\mathrm{Al}$ treatment (Table 1). During 2 days of growth, non-Al-stressed root of Chinese Spring increased $4.33 \mathrm{~cm}$, which was similar to most of the ditelosomic lines by the means over three replications. The root growth values of ditelosomic lines ranged from 2.15 to $6.03 \mathrm{~cm}$, with an average of $4.29 \mathrm{~cm}$, indicating significant variation in root growth among these ditelosomic lines under normal hydroponic growth conditions. When roots of the ditelosomic lines were exposed to $0.36 \mathrm{mM}$
Al, root growth was significantly reduced. But the root growth reduction due to Al stress differed significantly among ditelosomic lines. The SRG values for ditelosomic lines ranged from 0.29 to $1.98 \mathrm{~cm}$. DT5AL, DT7AL, DT2DS, DT4DS, DT1BS, DT7AS, and DT6DL showed significantly smaller SRG values than that of euploid Chinese Spring. Among them, reduction of SRG in lines DT5AL, DT7AL, DT2DS, DT4DS was statistically significant $(P=0.01)$. The RRI was also evaluated for these lines, and a highly significant correlation coefficient was observed between SRG and RRI $(r=0.82, P=0.01)$.

\section{QTLs for Al resistance in Chinese Spring}

Frequency distributions for root growth of the RILs and their parents under Al-stressed condition are summarized in Figure 1. The roots of two parents, CS-SM3DS7A and Annong 8455 showed differential responses to Al stress: the former had larger values for SRG and RRI, therefore is more resistant to Al. The frequency of distributions for SRG and RRI in the RIL population was basically normal distribution, indicating $\mathrm{Al}$ resistance in this genetic population was controlled by multiple genes. Broad sense heritability was high with 0.80 for SRG and 0.85 for RRI, suggesting that $\mathrm{Al}$ resistance is a highly heritable trait, and the genetic variation can be used in a wheat-breeding program for improving Al resistance.

After 1013 pairs of SSR and 112 AFLP primers were screened for polymorphism between parents, 381 AFLP markers and 168 SSR markers were selected to construct a genetic linkage map with a coverage of $2512 \mathrm{cM}$ length and can be assigned to all 21 chromosomes based on previously published map information for known SSR markers in the map (Guyomarc'h et al., 2002; Pestsova et al., 2000; Röder et al., 1998; Somers et al., 2004; Sourdille et al., 2003).

Composite interval mapping was used for identification of significant QTLs for root growth under Al stress, the threshold of LOD for each linkage group was calculated by a permutation test method with 1000 permutations at different $P$-values to determine a significant QTL (Table 2). Three QTLs, Qalt.pser-4D, Qalt.pser$5 A$ and Qalt.pser-2D, for SRG reached or 
Table 1. Aluminum sensitivity of ditelosomic lines and euploid of wheat cultivar Chinese Spring as reflected by mean and standard deviation of CRG (Control root growth), SRG (Stress root growth) and RRI (Root resistance index) over three experiments

\begin{tabular}{|c|c|c|c|c|}
\hline $\begin{array}{l}\text { Ditelosomic } \\
\text { line }\end{array}$ & $\begin{array}{l}\text { Missing chromosome } \\
\text { fragment }\end{array}$ & $\begin{array}{l}\mathrm{CRG} \\
(\mathrm{cm})^{\mathrm{a}}\end{array}$ & $\begin{array}{l}\mathrm{SRG} \\
(\mathrm{cm})^{\mathrm{a}}\end{array}$ & $\begin{array}{l}\text { RRI } \\
(\%)^{\mathrm{a}}\end{array}$ \\
\hline DT1AS & $1 \mathrm{AL}$ & $2.40 \pm 0.34^{*}$ & $1.49 \pm 0.17$ & $62.04 \pm 6.90$ \\
\hline DT1AL & $1 \mathrm{AS}$ & $5.17 \pm 1.25$ & $1.43 \pm 0.43$ & $27.74 \pm 5.85$ \\
\hline DT2AS & $2 \mathrm{AL}$ & $3.50 \pm 1.25$ & $1.59 \pm 0.21$ & $45.40 \pm 6.25$ \\
\hline DT3AS & $3 \mathrm{AL}$ & $4.50 \pm 0.98$ & $1.31 \pm 0.37$ & $29.14 \pm 8.34$ \\
\hline DT3AL & $3 \mathrm{AS}$ & $5.70 \pm 1.69$ & $1.66 \pm 0.47$ & $29.04 \pm 8.30$ \\
\hline DT4AL & $4 \mathrm{AS}$ & $3.10 \pm 1.05$ & $0.93 \pm 0.18$ & $30.11 \pm 6.20$ \\
\hline DT5AL & $5 \mathrm{AS}$ & $6.03 \pm 0.95$ & $0.29 \pm 0.06^{* *}$ & $4.79 \pm 0.21 * *$ \\
\hline DT6AS & $6 \mathrm{AL}$ & $5.34 \pm 1.37$ & $1.17 \pm 0.05$ & $21.83 \pm 0.91$ \\
\hline DT6AL & $6 \mathrm{AS}$ & $5.70 \pm 1.50$ & $0.96 \pm 0.61$ & $16.76 \pm 4.32 *$ \\
\hline DT7AS & $7 \mathrm{AL}$ & $4.03 \pm 1.46$ & $0.71 \pm * 0.27$ & $17.63 \pm 2.25^{*}$ \\
\hline DT7AL & 7AS & $4.40 \pm 0.28$ & $0.37 \pm 0.09^{* *}$ & $8.33 \pm 0.96^{* *}$ \\
\hline DT1BS & $1 \mathrm{BL}$ & $4.37 \pm 0.39$ & $0.49 \pm 0.05^{*}$ & $11.20 \pm 4.9 *$ \\
\hline DT1BL & $1 \mathrm{BS}$ & $3.65 \pm 1.02$ & $1.51 \pm 0.41$ & $41.40 \pm 8.36$ \\
\hline DT2BL & 2BS & $4.02 \pm 1.67$ & $1.10 \pm 0.05$ & $27.36 \pm 1.43$ \\
\hline DT3BS & $3 B L$ & $4.15 \pm 1.54$ & $1.98 \pm 0.34$ & $47.66 \pm 9.02$ \\
\hline DT3BL & $3 \mathrm{BS}$ & $4.10 \pm 0.88$ & $0.87 \pm 0.29$ & $21.14 \pm 7.22$ \\
\hline DT4BS & $4 \mathrm{BL}$ & $3.90 \pm 0.79$ & $1.39 \pm 0.19$ & $35.61 \pm 4.79$ \\
\hline DT5BL & $5 \mathrm{BS}$ & $5.00 \pm 1.56$ & $1.35 \pm 0.10$ & $27.00 \pm 2.16$ \\
\hline DT6BS & $6 \mathrm{BL}$ & $3.73 \pm 3.73$ & $1.45 \pm 0.37$ & $38.84 \pm 7.52$ \\
\hline DT6BL & $6 \mathrm{BS}$ & $3.65 \pm 0.66$ & $1.35 \pm 0.03$ & $36.99 \pm 0.79$ \\
\hline DT7BS & $7 \mathrm{BL}$ & $5.30 \pm 1.78$ & $1.16 \pm 0.33$ & $21.91 \pm 6.26$ \\
\hline DT7BL & 7BS & $2.77 \pm 0.86^{*}$ & $1.60 \pm 0.21$ & $57.83 \pm 7.74$ \\
\hline DT1DS & $1 \mathrm{DL}$ & $2.15 \pm 0.54^{*}$ & $1.08 \pm 0.11$ & $50.13 \pm 5.16$ \\
\hline
\end{tabular}


Table 1. Continued.

\begin{tabular}{|c|c|c|c|c|}
\hline $\begin{array}{l}\text { Ditelosomic } \\
\text { line }\end{array}$ & $\begin{array}{l}\text { Missing chromosome } \\
\text { fragment }\end{array}$ & $\begin{array}{l}\mathrm{CRG} \\
(\mathrm{cm})^{\mathrm{a}}\end{array}$ & $\begin{array}{l}\mathrm{SRG} \\
(\mathrm{cm})^{\mathrm{a}}\end{array}$ & $\begin{array}{l}\text { RRI } \\
(\%)^{\mathrm{a}}\end{array}$ \\
\hline DT1DL & $1 \mathrm{DS}$ & $3.35 \pm 1.29$ & $1.17 \pm 0.26$ & $34.83 \pm 7.78$ \\
\hline DT2DS & $2 \mathrm{DL}$ & $5.90 \pm 0.78$ & $0.34 \pm 0.16^{* *}$ & $5.78 \pm 1.80 * *$ \\
\hline DT4DS & $4 \mathrm{DL}$ & $4.00 \pm 0.84$ & $0.38 \pm 0.04 * *$ & $9.58 \pm 1.10^{* *}$ \\
\hline DT4DL & 4DS & $5.23 \pm 1.34$ & $1.23 \pm 0.24$ & $23.46 \pm 4.69$ \\
\hline DT5DL & $5 \mathrm{DS}$ & $3.90 \pm 0.93$ & $1.48 \pm 0.19$ & $38.03 \pm 4.95$ \\
\hline DT6DS & $6 \mathrm{DL}$ & $4.50 \pm 1.57$ & $0.96 \pm 0.20$ & $21.36 \pm 4.59$ \\
\hline DT6DL & $6 \mathrm{DS}$ & $4.65 \pm 0.98$ & $0.84 \pm 0.26^{*}$ & $18.16 \pm 5.70^{*}$ \\
\hline DT7DL & 7DS & $4.78 \pm 1.45$ & $1.04 \pm 0.30$ & $21.73 \pm 6.34$ \\
\hline Chinese Spring & 0 & $4.33 \pm 1.03$ & $1.22 \pm 0.40$ & $28.21 \pm 7.84$ \\
\hline
\end{tabular}

$*$ and ** indicate significant difference between ditelosomic line and euploid of Chinese Spring at $p=0.05$ and $p=0.01$ level, respectively, in a LSD test.
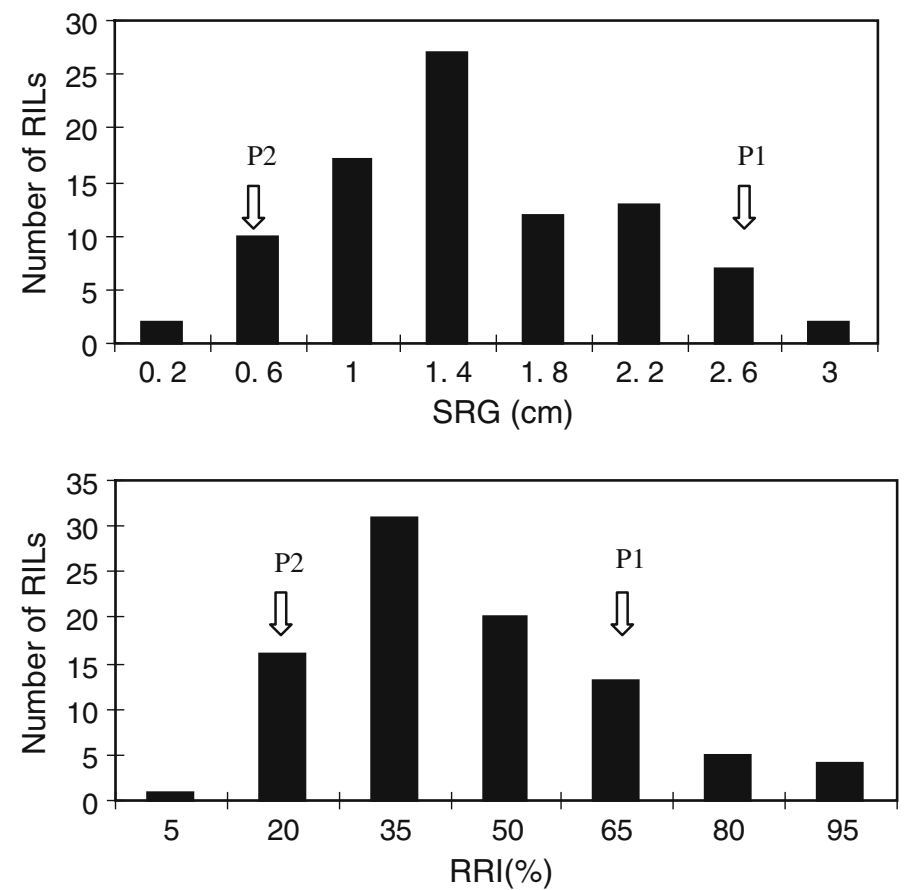

Figure 1. Frequency distributions of stress root growth (top) and root resistant index (bottom) of RILs. The values were the means over three experiments. P1 and P2 represent $\mathrm{A} 1$ resistant parent and sensitive parent, respectively. 


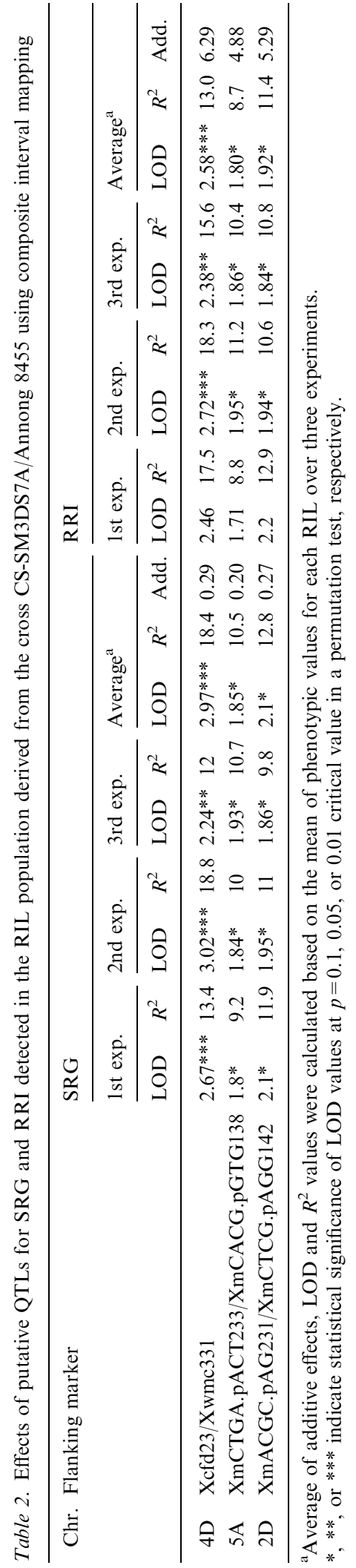

exceeded the LOD threshold for declaring the presence of a QTL, which explained $18.4 \%$, $10.5 \%$, and $12.8 \%$ of phenotypic variance, respectively. Among them, the Qalt.pser- $4 D$ with the largest effect on $\mathrm{Al}$ resistance is located on chromosome 4DL and is flanked by the markers of $X c f d 23$ and $X w m c 331$ (Figure 2). The QTL for RRI was also identified in the same region, and explained $13.0 \%$ of phenotypic variance of RRI. The Qalt.pser-5A and Qalt.pser-2D, located on chromosome 5A and 2D, were flanked by AFLP markers XmCTGA.pACT233 and XmCACG.pGTG138, and XmACGC.pAG231 and XmCTCG.pAGG142, respectively. The LOD values for the two QTLs were lower than that of Qalt.pser-4D, and were only marginally significant for both SRG and RRI. However, since these QTLs were detected in the three separate experiments performed (except for QTL on 5A for RRI in the first experiment), they suggested that genes on $5 \mathrm{~A}$ and $2 \mathrm{D}$ do condition a percentage of the measured Al resistance in this population. For all three QTLs on chromosome 4D, 2D and 5A, the alleles conferring Al resistance was originated from Chinese Spring based on the comparison of alleles among CS-SM3DS7A, Chinese Spring, Annong 8455 and Sumai 3 (Figure 3).

\section{Discussion}

In wheat breeding programs, wheat plants are usually evaluated for Al resistance in acidic soils under field conditions. However, inconsistent phytotoxicity among plots may significantly increase environmental error and decrease accuracy of phenotypic data. In addition, non-stressed treatments are usually applied in a different field with normal soil $\mathrm{pH}$, which may not provide a valid control for proper comparison. An alternative method for evaluating $\mathrm{Al}$ resistance is based on the use of a nutrient solution containing a toxic level of Al. Therefore, it has been widely used in genetic studies (Baier et al., 1995; Polle et al., 1978; Samac and Tesfaye, 2003). With this method, root growth rate during Al stress was measured to determine Al resistance of ditelosomic lines of Chinese Spring and RILs from the cross of Chinese Spring-Sumai 3 chromosome 7A substitution line and Annong 8455 in this study. 

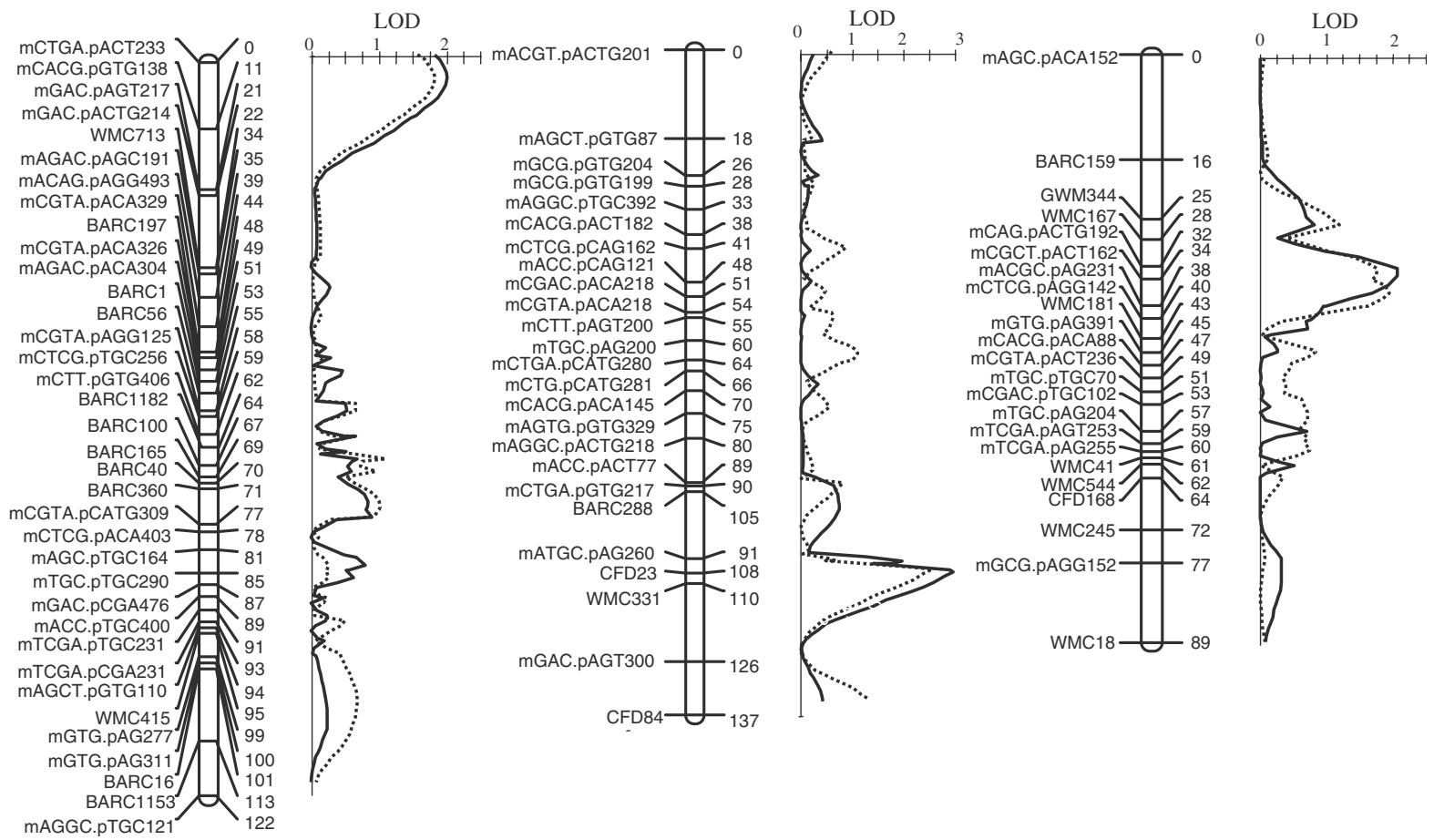

Figure 2. The QTLs on chromosome 2D (left), 4D (middle) and 5A (right) derived by composite interval mapping based on the average of three experiments. The distance between markers is given in Kosambi centiMorgans. — SRG, ...... RRI.

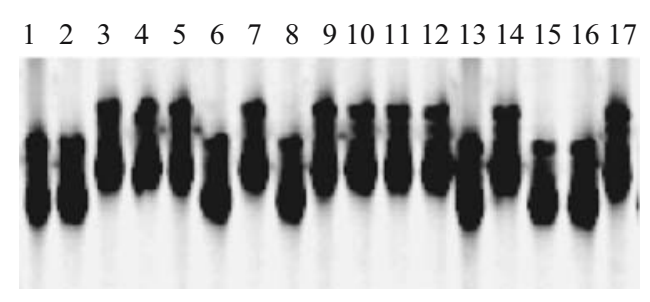

Figure 3. An electrophoresis pattern of PCR products amplified by SSR primer WMC 331 on a Li-Cor 4200 DNA analyzer. DNA samples from left to right are: 13 individuals of the RILs (1-13), cultivars Annong 8455 (14), CS-SM3DS7A (15), Chinese Spring (16) and Sumai 3 (17).

As a result, three QTLs for Al resistance were identified in the population.

Studies on Al resistance using a set of aneuploid lines of Chinese Spring indicated that genes controlling Al resistance were located on a number of different chromosome arms. Aniol and Gustafson (1984) located the genes for Al resistance on six chromosomes (6AL, 7AS, 2DL, 3DL, 4DL and 4BL) by testing 25 ditelosomic lines of Chinese Spring. Further work indicated that three factors controlling $\mathrm{Al}$ resistance in Chinese Spring might be on chromosome 5AS, 2DL and 4DL when plants were tested with different Al concentrations (Aniol, 1990). Papernik et al. (2001) confirmed that three chromosome arms, 4DL, 5AS and 7AS, possessed gene(s) for Al resistance when 27 ditelosomic lines of Chinese Spring were evaluated for root re-growth in the presence of A1. Ditelosomic line DT2DS was not tested in that experiment due to lack of enough seeds. In this experiment, 31 ditelosomic lines of Chinese Spring were tested. Among them, lines DT3AS, DT6AS, DT2BL, DT3BS and DT1DS have not been tested previously. Lines DT4DS, DT5AL, DT2DS and DT7AL showed a significant decrease in root re-growth after $\mathrm{Al}$ stress in this experiment, indicating that the genes conditioning Al resistance in Chinese Spring might be on these missing arms of these lines. This result confirmed the previous reports on $\mathrm{Al}$ resistance of the ditelosomic lines of Chinese Spring (Aniol 1990; Aniol and Gustafson 1984; Papernik et al. 2001). In addition, ditelosomic lines DT1BS, DT7AS and DT6DL also 
reduced root growth in the presence of $\mathrm{Al}$, but they were not statistically significant.

To determine individual QTL effects of all these chromosome arms on Al resistance, genome mapping with molecular markers has been used to determine the number and location of these QTLs in this study. Three regions on three different chromosomes showed effects on root growth under Al stress. The Qalt.pser-4D, Qalt.pser-5A, and Qalt.pser-2D were located on chromosome 4DL, 5AS, and 2DL, respectively. The QTL mapping result is in agreement with the result from evaluation of ditelosomic lines.

The QTL most strongly associated with Al resistance was on chromosome 4DL, and flanked by markers $X c f d 23$ and $X w m c 331$, the allele comparison showed that the Al resistance was from Chinese Spring. The QTL on chromosome 4DL was also identified in several previous reports. Riede and Anderson (1996) identified an RFLP marker $(X b c d 1230)$ tightly linked to the $A l t_{B H}$ gene on chromosome 4DL in wheat BH1146. Further studies confined $A l t_{B H}$ to a $5.9-\mathrm{cM}$ interval between markers $X g d m 125$ and $X p s r 914$ (Rodriguez-Milla and Gustafson, 2001). We also mapped a locus on the same region (flanked by markers $X w m c 331$ and $X g d m 125$ ) of Atlas 66 by using RILs from the cross of Atlas 66/Century (Ma et al., 2005). Because both BH1146 and Atlas 66 shared a common progenitor Polyssu, a Brazilian wheat with a high level of $\mathrm{Al}$ resistance (Foy et al., 1965), Al resistance in BH 1146 and Atlas 66 may be the same locus. Using disomic substitution lines with the D genome of Chinese Spring individually substituted by their homoeologues from Triticum turgidum L. cv. Langdon, Luo and Dvorak (1996) identified the Alt2 gene for Al resistance (flanked by RFLP markers Xps914 and Xpsr1051), also on chromosome 4DL of Chinese Spring. Further study indicated that Alt $_{B H}$ and Alt2 might be in the same chromosome region (Rodriguez-Milla and Gustafson, 2001). The result in this study further supports that a locus on 4DL of Chinese Spring is most likely located on the same region as in Atlas 66 and BH 1146, because the QTL from the Atlas 66 and $\mathrm{BH} 1146$ links to the SSR markers $X g d m 125$ and $X w m c 331$, and Xwmc331 is also the closest marker to Qalt.pser-4D in Chinese Spring. However, they are most likely different alleles, as the marker Xwmc331 shows different sizes of the band between Atlas 66 and Chinese Spring. In addition, Qalt.pser-CS4D in Chinese Spring has a much smaller effect than that in Atlas 66 and also expresses as a different allele of the ALMT1 gene, which encodes Al-induced malate transporter (Sasaki et al., 2004). This 4DL locus has been reported as a conserved genomic region for Al resistance across different species such as rye (Secale cereale L.) and barley (Hordeum vugare L.) (Miftahudin et al. 2002; Tang et al. 2000).

In addition to the 4DL locus, genes for $\mathrm{Al}$ resistance in other wheat chromosome regions have never been confirmed by molecular marker mapping (Kochian et al., 2004; Samac and Tesfaye, 2003). In this study, two minor QTLs were identified to associate with $\mathrm{Al}$ resistance in Chinese Spring. The Qalt.pser-CS5A was located on chromosome 5AS, which coincides with the results from evaluation of ditelosomic lines in this study and by Aniol (1990) and Papernik et al. (2001). Another putative QTL, Qalt.pser-2D, was detected on chromosome 2DL, with a marginally significant LOD value. The chromosome 2DL was also identified as a chromosome arm associated with $\mathrm{Al}$ resistance in the present and previous studies on ditelosomic lines of Chinese Spring for Al resistance (Aniol, 1990; Aniol and Gustafson, 1984). Thus chromosome arm 5AS and 2DL of Chinese Spring most likely contain minor QTLs for Al resistance.

DT7AL also showed a highly significant reduction in root growth, but the QTL was not significant from QTL mapping. The results could be due to that $7 \mathrm{~A}$ chromosome of the $\mathrm{Al}$ resistant parent was substituted by the same chromosome of Sumai 3 in this experiment, so effect of chromosome 7A of Chinese Spring on Al resistance could not be determined by molecular mapping in the study, though ditelosomic line DT7AL had significantly slower root regrowth than that for Chinese Spring under Al stress.

\section{Acknowledgements}

We thank Dr. Gill from Wheat Genetics Resource Center, Kansas State University, Manhattan, KS to provide seeds of Chinese Spring 
ditelosomic lines. This paper reports the results of research only. Mention of trade names or commercial products in this article is solely for the purpose of providing specific information and does not imply recommendation or endorsement by the U.S. Department of Agriculture. This is contribution No. 05-247-5 from the Kansas Agricultural Experiment Station, Manhattan, KS, USA.

\section{References}

Aniol A 1990 Genetics of tolerance to aluminum in wheat (Triticum aestivum L Thell). Plant Soil 123, 223-227.

Aniol A and Gustafson J P 1984 Chromosome locations of genes controlling aluminum tolerance in wheat, rye, and triticale. Can. J. Genet. Cytol. 26, 701-705.

Baier A C, Somers D J and Gustafson J P 1995 Aluminum tolerance in wheat: Correlating hydroponic evaluation with field and soil performances. Plant Breed. 114, 292-296.

Delhaize E and Ryan P R 1995 Aluminum toxicity and tolerance in plants. Plant Physiol. 103, 685-693.

Delhaize E, Craig S, Beaton C D, Bennet R J, Jagadish V C and Randall P J 1993 Aluminum tolerance in wheat (Triticum aestivum L.) I. Uptake and distribution of aluminum in root apices. Plant Physiol. 103, 685-693.

Foy C D, Armiger W H, Briggle L W and Reid D A 1965 Differential aluminum tolerance of wheat and barley varieties in acid soils. Agron. J. 66, 751-758.

Guyomarc'h H, Sourdille P, Edwards K J and Bernard M 2002 Studies of the transferability of microsatellite derived from Triticum taushchii to hexaploid wheat and to diploid related species using amplification, hybridization and sequence comparisons. Theor. Appl. Genet. 105, 736-744.

Jackson T and Reisenauer H 1984 Crop response to lime in western United States. In Soil Acidity and Liming. Ed. F Adams. pp. 333-347. American Society of Agronomy, Crop Science Society of America, Soil Science Society of America.

Kochian L V 1995 Cellular mechanisms of aluminum toxicity and resistance in plants. Annu. Rev. Plant Physiol. Mol. Biol. 46, 237-260.

Kochian L V, Hoekenga O A and Pineros M A 2004 How do crop plants tolerate acid soils? Mechanisms of aluminum tolerance and phosphorous efficiency. Annu. Rev. Plant Biol. 55, 459-493.

Luo M C and Dvorak J 1996 Molecular mapping of an aluminum tolerance locus on chromosome 4D of Chinese Spring wheat. Euphytica 91, 31-35.

Ma H X, Bai G H, Carver B F and Zhou L L 2005 Molecular mapping of a quantitative trait locus for aluminum tolerance in wheat cultivar Atlas 66. Theor. Appl. Genet. 112, $51-57$.

Magalhaes J V, Garvin D F, Wang Y, Sorrells M E, Klein P E, Schaffert R E, Li L and Kochian L V 2004 Comparative mapping of a major aluminum tolerance gene in Sorghum and other species in the Poaceae. Genetics 167, 1905-1914.

Miftahudin, Scoles G J and Gustafson J P 2002 AFLP markers tightly linked to the aluminum-tolerance gene Alt3 in rye (Secake cereale L.). Theor. Appl. Genet. 104, 626-631.
Miftahudin, Scoles G J and Gustafson J P 2004 Development of PCR-based codominant markers flanking the Alt3 gene in rye. Genome 47, 231-238.

Nguyen B D, Brar D S, Bui B C, Nguyen T V, Pham L N and Nguyen H T 2003 Identification and mapping of the QTL for aluminum tolerance introgressed from new source, Oryza rufipogon Griff., into indica rice (Oryza sativa L.). Theor. Appl. Genet. 106, 583-593.

Nguyen V T, Burow M D, Nguyen H T, Le B T, Le T D and Paterson A H 2001 Molecular mapping of genes conferring aluminum tolerance in rice (Oryza sativa L.). Theor. Appl. Genet. 102, 1002-1010.

Papernik L A, Bethea A S, Singleton T E, Magalhaes J V, Garvin D F and Kochian L V 2001 Mechanistic basis of Al sensitivity in the ditelosomic lines of Chinese Spring wheat. Planta 212, 829-834.

Pestsova E, Ganal M W and Roder M S 2000 Isolation and mapping of microsatellite markers specific for the $\mathrm{D}$ genome of breed wheat. Genome 43, 689-697.

Polle E, Konzak C F and Kittrick J A 1978 Visual detection of aluminum tolerance levels in wheat by hematoxylin staining of seedling roots. Crop Sci. 18, 823-827.

Riede C R and Anderson J A 1996 Linkage of RFLP markers to an aluminum tolerance gene in wheat. Crop Sci. 36, 905-909.

Röder M S, Korzum V, Wendehake K, Plaschke J, Tixier M H, Leroy P and Ganal M W 1998 A microsatellite map of wheat. Genetics 149, 2007-2023.

Rodriguez-Milla M A and Gustafson J P 2001 Genetic and physical characterization of chromosome 4DL in wheat. Genome 44, 883-892.

Ryan P R, Delhaize E and Randall P J 1995 Characterization of Al-stimulated efflux of malate from the apices of Al-tolerant wheat roots. Planta 196, 103-110.

Samac D A and Tesfaye M 2003 Plant improvement for tolerance to aluminum in acid soil-a review. Plant Cell Tissue Organ Cult. 75, 189-207.

Sasaki T, Yamamoto Y, Ezaki B, Katsuhara M, Ahn S J, Ryan P R, Delhaize E and Matsumoto H 2004 A wheat gene encoding an aluminum-activated malate transporter. Plant J. 37, 645-653.

Sibov S T, Gaspar M, Silva M J, Ottoboni L M M, Arruda P and Souza A P 1999 Two genes control aluminum tolerance in maize, genetic and molecular mapping analyses. Genome 42, 475-482.

Somers D J, Isaac P and Edwards K 2004 A high-density microsatellite consensus map for bread wheat (Triticum aestivium L.). Theor. Appl. Genet. 109, 1105-1114.

Song Q J, Shi J R, Singh S E, Fickus W J, Costa M, Lewis J, Gill B S, Ward R and Cregan P B 2005 Development and mapping of microsatellite (SSR) markers in wheat. Theor. Appl. Genet. 110, 550-560.

Sourdille P, Cadalen T, Guyomarc'h H, Snape J W, Perretant M R, Charmet G, Boeuf C, Bernard S and Bernard M 2003 An update of the Courtot $\times$ Chinese Spring intervarietal molecular marker linkage map for the QTL detection of agronomic traits in wheat. Theor. Appl. Genet. 106, 530-538.

Takagi H, Namai H and Murakami K 1983 Exploration of aluminum tolerance genes in wheat. In Proceedings 6th International Wheat Genetics Symposium. Ed. S Sakamoto. pp. 143-146. Plant Germplasm Istitute, Faculty of Agriculture, Kyoto University, .

Tang Y, Sorrells M E, Kochian L V and Garvin D G 2000 Identification of RFLP markers linked to barley aluminum tolerance gene Alp. Crop Sci. 40, 778-782. 
Taylor G J 1988 The physiology of aluminum tolerance. In Metal lons in Biological Systems: Aluminum and its Role in Biology. Eds. H Sigel and A Siger. pp. 165-198. Marcel Dekker, New York.

Van Ooijen J W and Voorrips R E 2001 JoinMap®3.0, Software for the Calculation of Genetic Linkage Maps. Plant Research International.

Van Ooijen J W 2004 MapQTL® 5, Software for Mapping of Quantitative Trait Loci in Experimental Populations. Kyazma B.V Wageningen Netherlands.

Wood S, Seastian K and Scherr S 2000 Soil resource condition. In Pilot Analysis of Global Ecosystems. pp. 45-54. Interna- tional Food Policy Research Institute and the World Resources Institute, Washington, DC, USA.

Wu P, Liao C Y, Hu B, Yi K K, Jin W Z, Ni J J and He C 2000 QTLs and epistasis for aluminum tolerance in rice (Oryza sativa L.) at different seedling stages. Theor. Appl. Genet. 100, 1295-1303.

Zhou W, Kolb F L, Bai G, Domier L L and Yao J 2002 Effect of individual Sumai 3 chromosome on resistance to scab spread within spikes and deoxynivalenol accumulation within kernels. Hereditas 137, 81-89.

Section editor: H. Lambers 